LAST month Madame Simone Weil, minister of health, declared that "the Pasteur Institute is no longer able to survive with only the help of its own resources," and deplored the fact that the prestigious institution "had been run by scientists who did not always possess the qualities of administrators."

Now the financial situation of the Institute is being examined by the Cour des Comptes, the government's accounting agency. When this report is completed, Madame Weil is to meet the institute's administrators and representatives of the scientific personnel in an attempt to find a solution for the Pasteur Institute "to continue its work in favourable conditions, either through increases in government subsidies, or by the State taking over some of its expenses."

The objective, says the dynamic and popular minister of health, "is to come to a point where the Pasteur does not have to keep asking for an amount of money it needs. A coherent and continuous system must be set up to allow the Institute to find its equilibrium." The Ministry of Industrial and Scientific Development, and that of Education, are also involved in the discussions.

This latest crise is one of many that have beset the Pasteur Institute since 1967, when a severe financial crisis triggered the so-called "Pasteur Institute revolution," which was followed by the replacement of a number of ageing administrators by scientists, and the drafting of new statutes providing for the separation of research and production activities.

As the new president of the institute's board of administrators, Jacques Monod attempted to maintain the Pasteur's status as a private institution (although one playing a vital national role) and to balance its books. He introduced into the hallowed walls of the building where Pasteur had carried out his experiments, a down-to-earth businessman, Jean Hardy, who came from the food industry.

Arrangements had to be made for some of the institute's products to be marketed by the pharmaceutical industry, and this gave rise to awkward situations. For instance, the Laboratoires Roger Bellon held a license to sell some of the Pasteur Institute's vaccines and biological products. Roger

that it spreads rapidly on the surface of the stream, forming what has been described as "an almost monomolecular film". At the same time, it is found effective as far downstream as 50 kilometres from the point of release, which is some 200 metres above the first site to be dealt with in any one drop. This is in strong contrast to the range of the same material when
Bellon was then purchased by RhônePoulenc, which also happens to have a controlling interest in the Institut Mérieux, which was founded by a disciple of Pasteur and is the Pasteur Institute's most successful commercial competitor.

\section{Pasteur's progress}

from Alexander Dorozynski, Paris

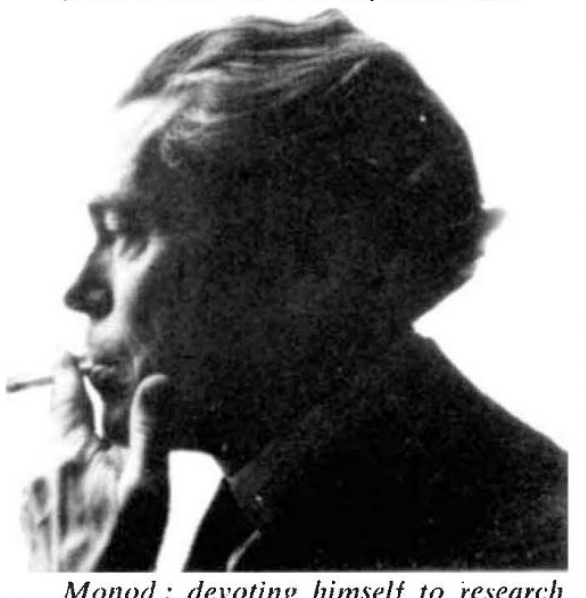

Monod: devoting himself to research

Two years ago, Institut Pasteur Productions, S.A. officially came into being, and took over commercial activities under the financial direction of Jean Hardy. Professor Monod agreed to head IPP temporarily as well as the Institute before returning entirely to scientific activities. It turned its profits over to the Pasteur Institute, but in spite of an annual production of some 17 million doses of serum and vaccines as well as of assorted biological testing products, and of substantial income from abroad from the licensing of the "prospective influenza vaccine" developed at Pasteur two years ago, ends wouldn't meet. The dream (which was defined by Professor Elie Wollman, associate director of the Institute, as that of a "socialist society of scientists, supported by a capitalist structure") just did not work out. The Pasteur got deeper into the red, and started eating up some of its capital, most of which came from the investment of donations of 2.5 million francs made at the time of the institute's founding in 1888 by contributors such as the Tsar of Russia, the Sultan of Turkey, and the Emperor of Brazil.

As a non-profit research organisation attempting to finance itself through a commercial subsidiary, it remained in a difficult position. There is little doubt that if IPP had decided to go into outright competition with the profitable French pharmaceutical industry, chances of success should have been good. But marketing "Pasteur Institute Aspirin" or other current drugs under the Pasteur label was not in the tradition. "We are not a drug company," said Prof. Wollman. "We don't sell drugs and I don't expect we shall."

Towards the end of last year, Professor Monod proposed his radical "renovation plan": to move away from the original location of the institute in the city (abandoning the laboratories, the research hospital, the historical library, as well as the grave of Pasteur), sell the 50,000 square metres of valuable real estate for some 250 million francs, and move to Garches, a few miles north of Paris, where the institute has the use of a large estate and has some production facilities.

The plan was opposed by a vast majority of the research staff, led by François Jacob. Last month Professor Monod resigned his post as president of the directors "to devote himself fully to stimulating scientific research at the institute". He was replaced by "businessman" Jean Hardy, who remains at the same time director of Pasteur Productions.

It has been pointed out that $\mathrm{Dr}$ Monod's return to scientific activity has been planned long ago, but perhaps it was triggered by a feeling (shared by some members of the Ministry of Health) that an outstanding scientist is not necessarily a good administrator.

At the same time a department of corporate development was created, now headed by Joël de Rosnay, a scientist with several years' experience in industry.

The Pasteur's problem is not so much to survive-that it undoubtedly will-but to survive while keeping its independence from state control and functionarization. This independence has not paid off in cash terms, but it seems to have paid off in terms of research. If the awarding of Nobel prizes is a criterion of value, the argument is a strong one; out of nine Nobel prizes awarded to Frenchmen in the fields of medicine and biology, eight have been given to pastoriens. applied by orthodox spraying techniques some 15-80 kilometres downstream.

The prototype equipment, designed by the COPR and made by CIBAPilatus for the WHO, was intended for use with fixed-wing aircraft and the first trials were carried out with a normal light aircraft. It has now been adapted for use with the helicopters to which the WHO is at present com- mitted on this project, partly because many of the rivers wind for miles through narrow walls of dense forest, where fixed-wing aircraft cannot safely be used. But on the larger and more open stretches, especially where sites to be treated are far apart, light aircraft may well prove more economical because of the much greater distances that they can cover. 